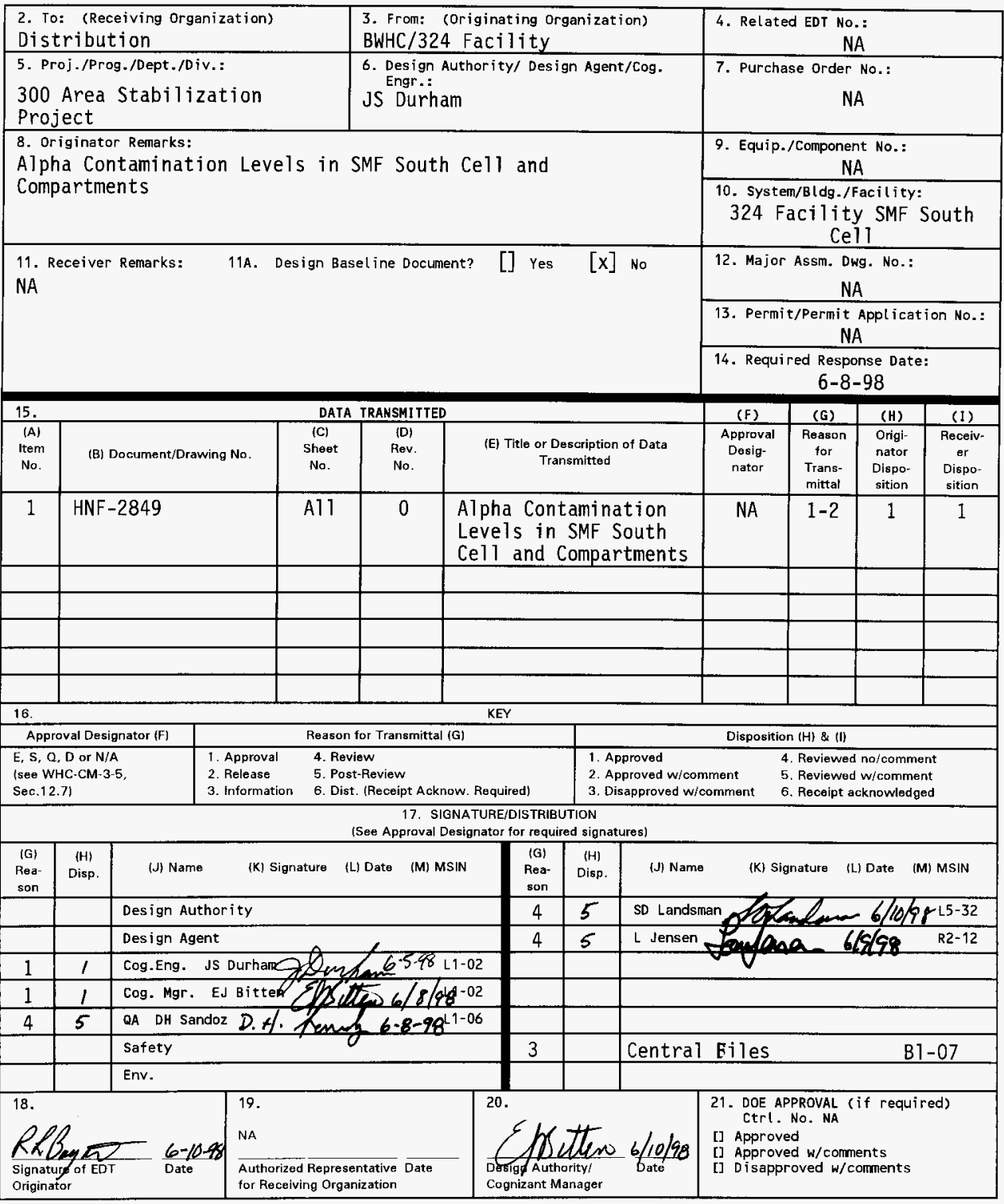


HNF-2849, Rev. 0 June 5,1998

\section{Alpha Contamination Levels in SMF South Cell and Compartments}

\section{JS Durham}

B\&W Hanford Company, Richland, WA 99352

U.S. Department of Energy Contract DE-AC06-96RL13200

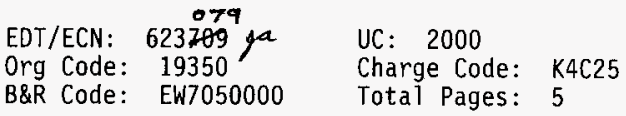

Key Words: Alpha contamination, South Ce11, SMF

Abstract: This document describes the detailed contamination survey performed in the Shielded Materials Facility (SMF) South Cell and the four compartments used during the $\mathrm{CsCl}$ activities.

TRADEMARK DISCLAIMER. Reference herein to any specific comercial product, process, or service by trade name, trademark, manufacturer, or otherwise, does not necessarily constitute or imply its endorsement, recommendation, or favoring by the United States Government or any agency thereof or its contractors or subcontractors.

Printed in the United States of America. To obtain copies of this document, contact: Document Control Services, P.0. Box 950, Mailstop H6-08, Richland WA 99352, Phone (509) 372-2420; Fax (509) 376-4989.
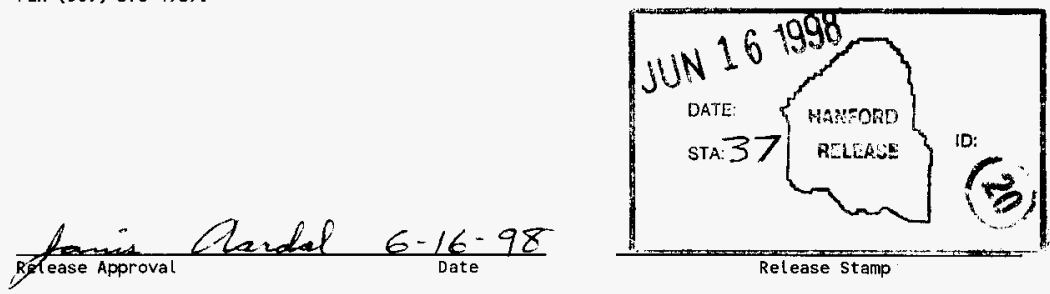

\section{Approved for Public Release}


HNF-2849, Rev. 0

June 5,1998

\section{Alpha Contamination Levels in SMF South Cell and Compartments}

\section{Purpose}

The purpose of this report is to document the results of a detailed contamination survey that was performed in the Shielded Materials Facility (SMF) South Cell, including the four compartments. Smears were obtained at each operating station in South Cell and analyzed at the 325 Building. The smear results indicate that the highest contamination levels are in Compartment 1 and South Cell proper, with significantly lower contamination levels measured in the other three compartments. Although some of the smears indicated the presence of alpha contamination, it will be shown that the source of the alpha contamination was cross-contamination during processing in the 325 Building hot cells and that the SMF is free of alpha contamination. The alpha-free status of South Cell is consistent with process knowledge of previous South Cell activities.

\section{Results and Discussion}

Duplicate smears were obtained from level surfaces at each operating station in South Cell and from both the walls and bottom of each compartment. The smear area was roughly $100 \mathrm{~cm}^{2}$. All smears were evaluated using gamma energy analysis (GEA) with a minimum detectable limit (MDL) of $5 \mathrm{E}-6 \mu \mathrm{Ci} /$ sample and one of each duplicate smear was evaluated using alpha energy analysis (AEA) with an MDL of $5 E-6 \mu \mathrm{Ci} / \mathrm{sample}$. The dose rates from smears obtained from the South Cell operating stations (stations 3 , 4 , and 10 through 13) and Compartment 1 (stations 8 and 9) were sufficiently high that they required remote handling. In addition, these smears required processing in the 325 Building hot cells prior to laboratory analysis. The 325 Building hot cells are highly contaminated with both beta-gamma and alpha-emitting radionuclides, so the use of "process blanks" was instituted to estimate the amount of contamination that was introduced into the south cell smears. The dose rates from smears obtained from compartments 2 through 4 (stations 5 through 7) had dose rates that allowed analysis in the laboratory without processing through the hot cells.

Although both the process blanks and the South Cell smears exhibited alpha contamination levels significantly higher than the MDL of the counting equipment, the alpha contamination levels of both were similar and it was necessary to establish a "Decision Level." A decision level is a value that enables the user to decide if a set of data is above or below a given level. In this case, the decision level was used to determine if South Cell was contaminated with alpha-emitting radionuclides. A decision level was established based on statistical considerations and the entire set of data was evaluated to determine if the decision level was exceeded. The alpha contamination level associated with each smear was weighted by the gamma contamination level (in 
HNF-2849, Rev. 0

June 5,1998

order to allow samples with different contamination levels to be compared) by dividing the alpha contamination level by the gamma contamination level. The ratios obtained from similar locations were then averaged. If the average was less than zero, that is, if the average was below the decision level, the smears were not contaminated with alpha contamination. A positive result would indicate the presence of alpha contamination in South Cell.

The results of the smear analyses are provided in Table 1. All smears that were processed through the 325 Building hot cells indicated alpha contamination. In order to evaluate if alpha contamination exists in South Cell, a decision level was established based on the results of analyzing 4 process blank samples. Process blank samples consist of either water or acid that was introduced to the 325 Building hot cell environment but that did not come into contact with the smears. The results of the analysis of process blanks are shown in Table 2.

Table 2. Process Blank Sample Results ( $\mu \mathrm{Ci} / \mathrm{sample}$ ) and Statistical Analysis

\begin{tabular}{|c|c|c|}
\hline Process Blanks & Alpha & Total gamma \\
\hline $98-2874 \mathrm{~PB}$ & $4.31 \mathrm{E}-04$ & $7.70 \mathrm{E}-03$ \\
\hline $98-2875 \mathrm{~PB}$ & $3.12 \mathrm{E}-03$ & $5.27 \mathrm{E}-02$ \\
\hline $98-2256 \mathrm{~PB}$ & $4.27 \mathrm{E}-4$ & $6.54 \mathrm{E}-03$ \\
\hline $98-2495 \mathrm{~PB}$ & $1.20 \mathrm{E}-03$ & $1.90 \mathrm{E}-02$ \\
\hline \multicolumn{2}{|c|}{} \\
\hline Mean & $1.58 \mathrm{E}-03$ & $2.15 \mathrm{E}-02$ \\
\hline Standard Deviation & $1.38 \mathrm{E}-03$ & $2.16 \mathrm{E}-02$ \\
\hline $\begin{array}{c}\text { One Sided 95\% } \\
\text { Confidence Interval }\end{array}$ & $3.21 \mathrm{E}-03$ & $4.69 \mathrm{E}-02$ \\
\hline
\end{tabular}

The decision level was determined by performing a statistical analysis of the 4 process blanks and obtaining a mean and standard deviation for both alpha and beta/gamma contamination. The decision level was determined by using quantiles from Student's $T$ Distribution to compute the upper limit to a one-sided $95 \%$ confidence interval on the mean. The data and limits are given in Table 2. For alpha contamination, the decision level was determined to be $3.21 \mathrm{E}-03 \mu \mathrm{Ci} / \mathrm{smear}$. The ratio of alpha contamination to gamma contamination level was then calculated. Because the number of process blanks was small and the standard deviation was high, the likelihood of observing "false 
HNF-2849, Rev. 0

June 5, 1998

\section{Table 1. South Cell Contamination Data ( $\mu \mathrm{Ci} / \mathrm{sample)}$}

\begin{tabular}{|c|c|c|c|c|c|c|c|c|c|}
\hline $\begin{array}{l}\text { Smear } \\
47 a\end{array}$ & $\begin{array}{c}\text { Location } \\
\text { South Cell Sta } 3\end{array}$ & $\begin{array}{c}\text { Gross } \\
\text { Alpha } \\
5.26 \mathrm{E}-3\end{array}$ & $\begin{array}{l}\text { Process } \\
\text { Alpha } \\
3.21 E-03\end{array}$ & $\begin{array}{c}\text { Net } \\
\text { Alpha } \\
\text { 2.05E-03 }\end{array}$ & $\begin{array}{c}\text { Gross } \\
\text { Gamma } \\
2.14 \mathrm{E}+2\end{array}$ & $\begin{array}{l}\text { Process } \\
\text { Gamma } \\
4.69 \mathrm{E}-02\end{array}$ & $\begin{array}{c}\text { Net } \\
\text { Gamma } \\
2.14 E+02\end{array}$ & $\begin{array}{l}\text { Average } \\
\text { Gamma } \\
2.51 \mathrm{E}+02\end{array}$ & $\begin{array}{c}\text { Alpha/Gamma } \\
\text { Ratio } \\
9.58 \mathrm{E}-06\end{array}$ \\
\hline $47 \mathrm{~b}$ & South Cell Sta 3 & & & & $2.88 E+2$ & 4.69E-02 & $2.88 \mathrm{E}+02$ & & \\
\hline $48 a$ & South Cell Sta 4 & $7.93 E-3$ & $3.21 E-03$ & 4.72E-03 & $1.00 E+1$ & 4.69E-02 & $9.96 \mathrm{E}+00$ & $9.90 \mathrm{E}+00$ & $4.74 \mathrm{E}-04$ \\
\hline $48 b$ & South Cell Sta 4 & & & & $9.89 E+0$ & 4.69E-02 & $9.84 E+00$ & & \\
\hline $49 a$ & South Cell Sta 11 & 1.87E-3 & 3.21E-03 & $-1.34 E-03$ & $5.26 \mathrm{E}+0$ & 4.69E-02 & $5.22 \mathrm{E}+00$ & $3.28 \mathrm{E}+00$ & $-2.58 \mathrm{E}-04$ \\
\hline $49 b$ & South Cell Sta 11 & & & & $1.40 \mathrm{E}+0$ & 4.69E-02 & $1.35 E+00$ & & \\
\hline $50 a$ & South Cell Sta 12 & $1.17 \mathrm{E}-3$ & $3.21 \mathrm{E}-03$ & $-2.04 \mathrm{E}-03$ & 4.27E+0 & 4.69E-02 & $4.23 E+00$ & $6.55 \mathrm{E}+00$ & $-4.83 E-04$ \\
\hline $50 \mathrm{~b}$ & South Cell Sta 12 & & & & $8.91 E+0$ & 4.69E-02 & $8.86 E+00$ & & \\
\hline $51 a$ & South Cell Sta 10 & $3.93 E-3$ & $3.21 E-03$ & 7.17E-04 & $3.01 E+0$ & 4.69E-02 & $2.96 \mathrm{E}+00$ & $6.39 E+00$ & 2.42E-04 \\
\hline $51 b$ & South Cell Sta 10 & & & & $9.86 \mathrm{E}+0$ & 4.69E-02 & $9.81 \mathrm{E}+00$ & & \\
\hline $52 a$ & South Cell Sta 13 & $3.46 \mathrm{E}-3$ & 3.21E-03 & 2.47E-04 & $1.68 \mathrm{E}+2$ & $4.69 \mathrm{E}-02$ & $1.68 E+02$ & $1.06 \mathrm{E}+02$ & 1.47E-06 \\
\hline $52 b$ & South Cell Sta 13 & & & & 4. $30 \mathrm{E}+1$ & $4.69 \mathrm{E}-02$ & 4.30E+01 & & \\
\hline $53 a$ & Compartment 4 & $<5 e-06$ & 0 & $<5 e-06$ & 6.75E-02 & 0 & $6.75 \mathrm{E}-02$ & $1.56 \mathrm{E}-01$ & $<5 \mathrm{e}-06$ \\
\hline $53 b$ & Compartment 4 & & & & 2.25E-01 & 0 & 2.25E $\sim 01$ & & \\
\hline $54 a$ & Compartment 4 & $<5 e-06$ & 0 & $<5 e-06$ & $1.74 \mathrm{E}-01$ & 0 & $1.74 \mathrm{E}-01$ & & \\
\hline $54 b$ & Compartment 4 & & & & $1.56 \mathrm{E}-01$ & 0 & $1.56 \mathrm{E}-01$ & & \\
\hline $55 a$ & Compartment 2 & $<5 e-06$ & 0 & $<5 e-06$ & $1.03 E-01$ & 0 & $1.03 \mathrm{E}-01$ & $1.20 \mathrm{E}-01$ & $<5 e-06$ \\
\hline $55 b$ & Compartment 2 & & & & $9.52 E-02$ & 0 & $9.52 E-02$ & & \\
\hline $56 a$ & Compartment 2 & $<5 e-06$ & 0 & $<5 \mathrm{e}-06$ & 1.50E-01 & 0 & $1.50 \mathrm{E}-01$ & & \\
\hline $56 \mathrm{~b}$ & Compartment 2 & & & & 1.31E-01 & 0 & $1.31 E-01$ & & \\
\hline $57 a$ & Compartment 3 & $<5 \mathrm{e}-06$ & 0 & $<5 \mathrm{e}-06$ & 4.98E-02 & 0 & $4.98 \mathrm{E}-02$ & 1.43E-01 & $<5 e-06$ \\
\hline $57 b$ & Compartment 3 & & & & 2.16E-01 & 0 & 2.16E-01 & & \\
\hline $58 a$ & Compartment 3 & $<5$ e-06 & 0 & $<5 e-06$ & 9.37E-02 & 0 & 9.37E-02 & & \\
\hline $58 b$ & Compartment 3 & & & & 2. 14E-01 & 0 & 2.14E-01 & & $\cdot$ \\
\hline $60 a$ & Compartment 1 & & & & $7.66 \mathrm{E}+1$ & 4.69E-02 & $7.66 \mathrm{E}+01$ & & \\
\hline $60 b$ & Compartment 1 & $1.68 \mathrm{E}-3$ & $3.21 \mathrm{E}-03$ & $-1.53 E-03$ & $7.73 E+2$ & 4.69E-02 & $7.73 E+02$ & $4.25 E+02$ & $-1.98 E-06$ \\
\hline $61 \mathrm{a}$ & Compartment 1 & 4.49E-3 & $3.21 E-03$ & $1.28 \mathrm{E}-03$ & $6.44 E+2$ & 4.69E-02 & $6.44 E+02$ & $8.42 E+02$ & 1.98E-06 \\
\hline $61 b$ & Compartment 1 & & & & $1.04 E+3$ & 4.69E-02 & $1.04 E+03$ & & \\
\hline
\end{tabular}


HNF-2849, Rev. 0 June 5, 1998

positive" data is high. In order to fully evaluate the smear data, the average ratio of alpha to gamma contamination was calculated for both South cell and Compartment 1. As shown in Table 3, it has been determined that the average ratio of alpha contamination to gamma contamination in South Cell and Compartment 1 are below the alpha contamination decision level, that is, the ratio is less than 0 . This indicates that SMF South Cell is not contaminated with alpha-emitting radionuclides.

Table 3. Average Ratio of Alpha to Gamma Contamination

\begin{tabular}{|c|c|}
\hline Location & Average alpha:gamma ratio \\
\hline South Cell & $-2.41 \mathrm{E}-06$ \\
\hline Compartment 1 & $-5.59 \mathrm{E}-10$ \\
\hline Compartment 2 & <detectable \\
\hline Compartment 3 & <detectable \\
\hline Compartment 4 & <detectable \\
\hline
\end{tabular}

The conclusion that South Cell is free from alpha contamination is further supported by the smears taken in Compartments 2 through 4 . These samples were processed in a contamination-free environment prior to analysis. None of the smears processed in the contamination-free environment exhibited alpha contamination above the detectable limit.

\section{Conclusion}

The analysis of the process blank samples and the lack of detectable alpha contamination in any of the samples processed in a contamination-free environment indicates that the SMF South Cell, including the compartments, is free of alpha contamination above detectable limits. Waste material exposed to the environment in South Cell and/or the compartments does not meet the conditions for designation as transuranic (TRU) waste. 